\title{
Phosphorus feeding practices, barriers to and motivators for minimising phosphorus feeding to dairy cows in diverse dairy farming systems
}

Article

Published Version

Creative Commons: Attribution 4.0 (CC-BY)

Open access

Harrison, B. P., Dorigo, M., Reynolds, C. K. ORCID:

https://orcid.org/0000-0002-4152-1190, Sinclair, L. A. and Ray, P. P. ORCID: https://orcid.org/0000-0001-8375-8279 (2021) Phosphorus feeding practices, barriers to and motivators for minimising phosphorus feeding to dairy cows in diverse dairy farming systems. Animal, 15 (7). 100248. ISSN 1751-7311 doi: https://doi.org/10.1016/j.animal.2021.100248 Available at https://centaur.reading.ac.uk/97218/

It is advisable to refer to the publisher's version if you intend to cite from the work. See Guidance on citing.

To link to this article DOI: http://dx.doi.org/10.1016/j.animal.2021.100248

Publisher: Elsevier

All outputs in CentAUR are protected by Intellectual Property Rights law, including copyright law. Copyright and IPR is retained by the creators or other copyright holders. Terms and conditions for use of this material are defined in the End User Agreement. 


\section{www.reading.ac.uk/centaur}

\section{CentAUR}

Central Archive at the University of Reading

Reading's research outputs online 


\title{
Phosphorus feeding practices, barriers to and motivators for minimising phosphorus feeding to dairy cows in diverse dairy farming systems
}

\author{
B.P. Harrison ${ }^{\text {a }}$, M. Dorigo ${ }^{b}$, C.K. Reynolds ${ }^{\text {a }}$, L.A. Sinclair ${ }^{c}$, P.P. Ray ${ }^{a, *}$ \\ ${ }^{a}$ Department of Animal Sciences, School of Agriculture, Policy and Development, University of Reading, RG6 6EU, UK \\ ${ }^{\mathrm{b}}$ AHDB Dairy, Agriculture and Horticulture Development Board, Stoneleigh Park, Kenilworth, Warwickshire CV8 2TL, UK \\ ${ }^{\mathrm{c}}$ Department of Agriculture and the Environment, Harper Adams University, Shropshire TF10 8NB, UK
}

\section{A R T I C L E I N F O}

\section{Article history:}

Received 10 September 2020

Revised 30 March 2021

Accepted 2 April 2021

\section{Keywords:}

Dairy farm

Nutrient management

Nutrition

Survey

Sustainability

\begin{abstract}
A B S T R A C T
Minimising phosphorus (P) feeding to dairy cows can reduce feed costs and minimise water pollution without impairing animal performance. This study aimed to determine current $\mathrm{P}$ feeding practices and identify the barriers to and motivators for minimising $P$ feeding on dairy farms, using Great Britain (GB) dairy farming as an example of diverse systems. Farmers $(n=139)$ and feed advisers $(n=31)$ were involved simultaneously in independent questionnaire surveys on P feeding in dairy farms. Data on the herd size, milk yield and concentrate fed were analysed using ANOVA to investigate the effect of farm classification, region, and feed professional advice. Chi-square tests were used to investigate associations between farm characteristics and implemented P feeding and management practices. Most farmers (72\%) did not know the $\mathrm{P}$ concentration in their lactating cow's diet and did not commonly adopt precision $\mathrm{P}$ feeding practices, indicating that cows might have been offered dietary $\mathrm{P}$ in excess of recommended $\mathrm{P}$ requirement. Farmers' tendency to feed $\mathrm{P}$ in excess of recommendations increased with herd size, but so did their awareness of P pollution issues and likeliness of testing manure P. However, $68 \%$ of farmers did not analyse manure $P$, indicating that mineral $P$ fertiliser application rates were not adjusted accordingly, highlighting the risk of $P$ being applied beyond crops' requirement. Almost all farmers (96\%) were willing to lower dietary P concentration but the uncertainty of P availability in feed ingredients (30\%) and concerns over reduced cow fertility (22\%) were primary barriers. The willingness to reduce dietary P concentrations was driven by the prospect of reducing environmental damage (28\%) and feed costs (27\%) and advice from their feed professionals (25\%). Most farmers (70\%) relied on a feed professional, and these farmers had a higher tendency to analyse their forage P. However, farmers of pasture-based systems relied less on feed professionals. Both farmers (73\%) and feed advisers (68\%) were unsatisfied with the amount of training on P management available. Therefore, the training on P management needs to be more available and the influence that feed professionals have over P feeding should be better utilised. Study findings demonstrate the importance of considering type of dairy farming systems when developing precision $\mathrm{P}$ feeding strategies and highlight the increasing importance of feed professionals in minimising $P$ feeding.
\end{abstract}

(c) 2021 The Author(s). Published by Elsevier B.V. on behalf of The Animal Consortium. This is an open access article under the CC BY license (http://creativecommons.org/licenses/by/4.0/).

\section{Implications}

Study findings highlight to policymakers and knowledge exchange bodies the need for training on effective phosphorus management in dairy farming systems to be made more available to farmers and feed professionals. The results further demonstrate the importance of considering type of dairy farming systems when developing precision $P$ feeding strategies.

\footnotetext{
* Corresponding author.

E-mail address: p.p.ray@reading.ac.uk (P.P. Ray).
}

\section{Introduction}

Globally, there has been increasing public concern about environmental pollution from livestock farming (Kebreab et al., 2013). In particular, eutrophication degrades water quality and reduces aquatic biodiversity, annually costing the United Kingdom (UK) an estimated minimum of $£ 229$ million (Moxey, 2012). Eutrophication is accelerated when waterbodies are enriched with phosphorus $(\mathbf{P})$ and a major source of $P$ enrichment is agricultural land that has received $\mathrm{P}$ above the crops' requirement. In the UK and in many European countries, land application of $\mathrm{P}$ is indirectly regulated by limits on the application of nitrogen via manure 
(European Commission, 1991). However, dairy cows excrete 60$80 \%$ of consumed $\mathrm{P}$ in faeces, and this faecal $\mathrm{P}$ excretion is positively correlated with dietary P intake (Knowlton and Ray, 2013). Therefore, feeding more $\mathrm{P}$ than required to dairy cows results in P-rich manure that contains an imbalanced nitrogen:P ratio, which makes it difficult to apply manure to land based on crops' nitrogen requirement without applying $\mathrm{P}$ beyond crops' $\mathrm{P}$ requirement (Knowlton and Ray, 2013). Since the P content in manure can vary, land application of manure $\mathrm{P}$ can be optimised via quantifying manure $P$ to adapt mineral fertiliser $P$ application rates by crediting the accurate amount of P present in manure (Svanback et al., 2019). However, minimising P feeding remains the optimal cost-effective approach to reduce the overapplication of $\mathrm{P}$ to land, especially in areas with a high soil $P$ index where farmers need to transport P-rich manure to further lands which will incur costs (Knowlton, 2011).

Dairy herds in England have been identified as feeding a dietary $P$ concentration higher than what is recommended by the National Research Council (NRC, 2001) for dairy cows (Sinclair and Atkins, 2015). Reducing dietary P concentrations to closely match NRC (2001) recommended concentrations reduces faecal P excretion without any negative impacts on health, productivity or fertility in dairy cows (Ferris et al., 2009; Wang et al., 2014). Additionally, eliminating or reducing the use of inorganic P supplements can save farmers' money (Kebreab et al., 2008) and can minimise the water soluble fraction of manure $P$ that is more prone to runoff (Dou et al., 2002). Therefore, the question that remains unanswered is 'why are excess amounts of P being fed in dairy farms?'

A driver of excess $P$ feeding in the United States (US) is the addition of a safety margin to dietary P concentrations (Dou et al., 2003) by farmers and feed professionals to ensure against reduced productivity and fertility (Knowlton, 2011), and as a substitute for quantifying forage $P$ concentration, which is highly variable (Kebreab et al., 2013). Testing forages for P is critical to adopt precision $\mathrm{P}$ feeding in all dairy farming systems because the variable contribution of $P$ from forages can then be accurately considered when formulating diets (Cerosaletti et al., 2004). However, frequent testing of forages for $\mathrm{P}$ is particularly important in countries such as the UK, Ireland and New Zealand where pasture-based systems use dairy cow diets comprised largely of forages (March et al., 2014). Formulating diets with $P$ concentrations specific to cows grouped according to their milk yield and stages of lactation is also recommended to precisely feed $P$ because a cow's $P$ requirement changes with the stage of growth, lactation and gestation (Kebreab et al., 2013). However, little is known about the adoption of such 'precision P feeding practices' by dairy farmers in countries operating diverse dairy farming systems.

The European dairy sector needs to improve its sustainability by improving the utilisation efficiency of feed nutrients, including $P$ (Augère-Granier, 2018). Dairy farming systems in North-western and central European countries are similar to Great Britain (GB), which operate large specialised dairy farms of high yielding cows along with a wide assortment of pasture-based and housed systems (March et al., 2014; Augère-Granier, 2018). However, most of the research into minimising $P$ feeding, which is based in the US where housed systems are common (Dou et al., 2003; Harrison et al., 2012), may not be relevant for many countries operating diverse dairy farming systems primarily because housed and pasture-based systems contribute to eutrophic risk differently from one another. Relatively high potential of $P$ loss per ton of milk solids and per hectare of farmland makes the housed systems a greater eutrophic risk than pasture-based systems, with the main contributor to eutrophic risk being the use of greater amount of concentrate feed leading to the generation of P-rich manure, whereas the eutrophic risk of housed and pasture-based systems are more similar on a total farmland basis, due to $\mathrm{P}$ loss from relatively large agricultural area following excreta deposition onto the land by grazing cattle and land application of fertiliser to support the growth of home-grown forages in pasture-based systems (O'Brien et al., 2012). Furthermore, the ease of implementing certain feeding practices may differ between dairy farming systems (March et al., 2014). Therefore, the current survey aims to fill the knowledge gap by assessing how farmers and feed advisers feed $P$ to dairy cows in diverse dairy farming systems and identifying factors that influence adoption of precision $\mathrm{P}$ feeding practices. The objectives of this study were to assess the current $P$ feeding practices used in dairy farms and to identify barriers to and motivators for achieving precision P feeding. The GB dairy farming system was used as an example of diverse dairy farming systems.

\section{Material and methods}

\section{Questionnaire survey: Great Britain dairy farmers}

A list of 6780 anonymised dairy farms was obtained from the Agriculture and Horticulture Development Board (AHDB), the dairy farmer levy body in GB, and farms were grouped by herd size and region. Two thousand dairy farms were then randomly selected using a stratified sampling approach and sent a copy of the survey by post in 2019. Additionally, an online version of the same anonymous survey was created using Qualtrics (https://www.qualtrics.com) and a link was distributed by relevant stakeholders (AHDB Dairy, British Grassland Society, Scottish Dairy Hub, Soil Association, Society of Feed Technologists, Feed Adviser Register and Agricology). The questionnaire consisted of 42 questions (10 openended and 32 closed), with multiple choices when applicable (Supplementary Table S1). Questions were developed from the literature and using contributions from relevant experts.

The questionnaire collected information on farm management practices including precision $P$ feeding practices and farmers' attitudes towards feeding lower dietary $\mathrm{P}$ concentrations to dairy cows. Farms were categorised into GB region (England, Scotland and Wales), whether or not they relied on a feed professional (nutritionist, feed supplier or veterinary) and farm classification (Supplementary Table S2). The five farm classifications are based on calving pattern, days of access to grazing and concentrate supplementation (Garnsworthy et al., 2019). Classification 1 farms adopt spring calving and graze $>274$ days a year with limited supplements. Classification 2, 3 and 4 farms adopt block or all year calving with increasing use of concentrate supplement as grazing days reduce. Classification 5 farms adopt all year round calving in a housed system with the greatest supplement use fed as a total mixed ration. The questionnaire was piloted on five dairy farms and revised prior to distribution.

\section{Questionnaire survey: Feed advisers to Great Britain dairy farms}

A questionnaire survey of dairy feed advisers was adapted from the farmer questionnaire. The feed adviser questionnaire was created on Qualtrics (https://www.qualtrics.com) with the anonymous link distributed by the same stakeholders used for the farmer survey. Paper copies were also distributed to relevant alumni of Harper Adams University and attendees of the Annual General Meet of the Society of Feed Technologists, 2019. Advisers were instructed to use one client farm when reporting practices throughout the survey.

\section{Statistical analysis}

The data from two questionnaire surveys were statistically analysed independent from one another. Not all respondents 
answered every question; therefore, the percentage of responses was calculated using the number of responses to the questions not the number of survey respondents. The dietary P concentration reported by the respondents was compared against recommended levels advised by the NRC (2001) using DM intake predictions (Kebreab et al., 2013) based on the annual milk yield stated by respondents.

For each survey, ANOVA and mean separation by Tukey's test were carried out using Minitab (Version 2019) to investigate the effect of 'farm classification', 'region', and 'feed professional advice' on 'herd size', 'annual milk yield' and 'annual concentrate fed'. Chi-square tests were used to investigate associations between farm characteristics and whether or not respondents reported being aware of $P$ pollution issues and implemented $P$ feeding and management practices. A binary logistic regression model was used to evaluate the relationship between 'herd size' and whether or not respondents reported being aware of $P$ pollution issues and implemented $\mathrm{P}$ feeding and management practices.

\section{Results}

Herd demographics

A total of 139 responses (126 postal and 13 online) were returned from the farmer survey with a mean herd size of 257 (range: 7-2 500 cows). Housed systems (classification 5) managed larger herds than pasture-based systems feeding some concentrate supplements (classifications 2 and 3; Table 1). The mean annual milk yield of participating farms was $7956 \mathrm{~kg} / \mathrm{cow}$, with housed systems managing higher producing cows than pasturebased systems (Table 1). The mean annual amount of concentrate fed across all systems was $2036 \mathrm{~kg} / \mathrm{cow}$. Pasture-based systems that relied most on grazing (classification 1) fed the least amount of concentrate and housed systems feeding total mixed ration (classification 5) fed more concentrate than pasture-based systems (classifications 1, 2 and 3; Table 1). Farms that used advice from feed advisers fed more concentrate to their cows and had greater milk yield compared to farms that did not have a feed professional (Table 1).
Farmers' knowledge of the phosphorus concentration in lactating cows' diet

More than two-thirds of farmers were unaware of the dietary $\mathrm{P}$ concentration in their lactating cows' diet (Table 2). A third of the 36 farmers, who stated that they knew the dietary P concentration, offered diets with an estimated concentration greater than recommended by the NRC (2001), but a smaller proportion offered diets in excess of what the Agricultural and Food Research Council (AFRC) (Suttle et al., 1991) recommend (Fig. 1). Two-thirds (62/93 [67\%]) of farmers that did not know the dietary P concentration relied on a feed professional but the remainder presumably formulated diets with no knowledge of its P concentration. Only a small proportion of farmers stated that they formulated diets following a recognised $\mathrm{P}$ feeding recommendation, and these farmers either followed the NRC (2001) recommendations (10/25 [40\%]) or the AFRC (Suttle et al. 1991) recommendations (6/25 [24\%]) with the remainder following various unrecognised recommendations.

Precision phosphorus feeding and management practices used by dairy farmers

Three-quarters of farmers fed a single diet to their entire milking herd (Table 2), primarily because it was an easier feeding strategy to adopt (45/98 [46\%]). Just over a third of all farmers stated that they used forage $\mathrm{P}$ test results when formulating diets (Table 2). Many farmers included inorganic P supplements in lactating cow diets (Table 2) and almost two-thirds of farmers gave no consideration to $P$ concentration when purchasing feed ingredients (Table 2). Manure was not analysed for P by two-thirds of farmers (Table 2). Almost three quarters of farmers stated that sufficient training on $\mathrm{P}$ management was not available to them (Table 2).

Factors influencing farmers' awareness of phosphorus pollution and phosphorus feeding and management practices

Pasture-based systems were less likely to use a feed professional compared to housed systems feeding total mixed ration (Table 3). The use of a feed professional increased the likelihood that a farm analyses forage for $\mathrm{P}$ but also tended to increase the

Table 1

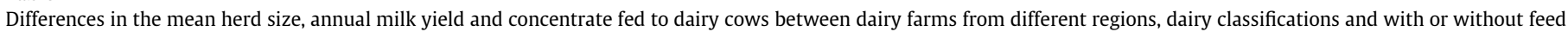
professional presence.

\begin{tabular}{|c|c|c|c|c|c|}
\hline Category & Sub Category & Respondents & Herd size (cow number) & Annual milk yield (kg/cow) & Concentrate fed $(\mathrm{kg} / \mathrm{cow})$ \\
\hline \multicolumn{6}{|l|}{ Region } \\
\hline & England & $80 / 139$ & 271 & $7630^{\mathrm{A}}$ & 1996 \\
\hline & Scotland & $39 / 139$ & 254 & $8866^{\mathrm{B}}$ & 2190 \\
\hline & Wales & 20 & 205 & $7560^{\mathrm{AB}}$ & 1898 \\
\hline & & & $(330)$ & $(2051)$ & $\left(\begin{array}{ll}1 & 184\end{array}\right)$ \\
\hline \multicolumn{6}{|l|}{ Classification $^{1}$} \\
\hline & 1 & $21 / 139$ & $393^{\mathrm{AB}}$ & $5662^{C}$ & $1003^{C}$ \\
\hline & 2 & $55 / 139$ & $182^{\mathrm{BC}}$ & $7479^{\mathrm{B}}$ & $1752^{\mathrm{B}}$ \\
\hline & 3 & $41 / 139$ & $153^{\mathrm{C}}$ & $8159^{\mathrm{B}}$ & $2245^{\mathrm{B}}$ \\
\hline & 4 & $4 / 139$ & $363^{\mathrm{ABC}}$ & $10888^{\mathrm{A}}$ & $2943^{\mathrm{AB}}$ \\
\hline & 5 & $18 / 139$ & $539^{\mathrm{A}}$ & $10831^{\mathrm{A}}$ & $3466^{\mathrm{A}}$ \\
\hline & & & $(303)$ & $(1512)$ & $(963)$ \\
\hline \multicolumn{6}{|l|}{ Feed professional } \\
\hline & Yes & $96 / 138$ & 248 & $8396^{\mathrm{A}}$ & $2235^{A}$ \\
\hline & No & $42 / 138$ & 260 & $6849^{\mathrm{B}}$ & $1562^{\mathrm{B}}$ \\
\hline & & & $(331)$ & $(1971)$ & $\left(\begin{array}{ll}1 & 143\end{array}\right)$ \\
\hline & & & $P$ values & & \\
\hline Region & & & $P>0.005$ & $P<0.001$ & $P>0.005$ \\
\hline Classification & & & $P<0.001$ & $P<0.001$ & $P<0.001$ \\
\hline Feed professional & & & $P>0.005$ & $P<0.001$ & $P<0.01$ \\
\hline
\end{tabular}

\footnotetext{
${ }^{1}$ Dairy farm classification based on calving and feeding approach (Garnsworthy et al., 2019), Values in parenthesis indicate pooled standard deviations.

A-C In a column, means within a category not sharing same superscripts differ significantly $(P<0.05)$.
} 
Table 2

Responses of Great Britain dairy farmers $(n=139)$ and feed advisers $(n=31)$ involved in a survey of phosphorus $(\mathrm{P})$ feeding to dairy cows and management practices and attitudes towards $\mathrm{P}$ feeding.

\begin{tabular}{|c|c|c|}
\hline Characteristics & $\begin{array}{l}\text { No. of } \\
\text { Farmers (\%) }\end{array}$ & $\begin{array}{l}\text { No. of } \\
\text { Advisers (\%) }\end{array}$ \\
\hline \multicolumn{3}{|l|}{$\begin{array}{l}\text { Aware of dietary P } \\
\text { concentration }\end{array}$} \\
\hline Yes & $36 / 129(28)$ & $25 / 30(83)$ \\
\hline No & $93 / 129(72)$ & $5 / 30(17)$ \\
\hline Blanks & 10 & 1 \\
\hline \multicolumn{3}{|l|}{$\begin{array}{l}\text { Feed } P \text { in excess of } \\
\text { recommendations }{ }^{1}\end{array}$} \\
\hline Yes & $12 / 36(33)$ & $13 / 25(52)$ \\
\hline No & $24 / 36(67)$ & $12 / 25(48)$ \\
\hline Blanks & 103 & 6 \\
\hline \multicolumn{3}{|l|}{ Use a feed professional } \\
\hline Yes & $96 / 138(70)$ & Not applicable \\
\hline No & $42 / 138(30)$ & Not applicable \\
\hline Blanks & 1 & \\
\hline \multicolumn{3}{|l|}{$\begin{array}{l}\text { Follow a } \\
\text { recommendation for } \\
\quad \mathrm{P} \text { feeding }\end{array}$} \\
\hline Yes & $25 / 136(18)$ & $22 / 26(85)$ \\
\hline No & $48 / 136(35)$ & $3 / 26(12)$ \\
\hline Don't know & $63 / 136(46)$ & $1 / 26(4)$ \\
\hline Blanks & 3 & 5 \\
\hline \multicolumn{3}{|l|}{$\begin{array}{l}\text { Formulate a single diet } \\
\text { for the milking herd }\end{array}$} \\
\hline Yes & $98 / 132(74)$ & $26 / 31(84)$ \\
\hline No & $34 / 132(26)$ & $5 / 31(16)$ \\
\hline Blanks & 7 & - \\
\hline \multicolumn{3}{|l|}{$\begin{array}{l}\text { Formulate diets using } \\
\quad \text { forage } \mathrm{P} \text { test results }\end{array}$} \\
\hline Yes & $49 / 131(37)$ & $23 / 31(74)$ \\
\hline No & $71 / 131(54)$ & $8 / 31(26)$ \\
\hline Don't know & $11 / 131(8)$ & - \\
\hline Blanks & 8 & - \\
\hline \multicolumn{3}{|l|}{$\begin{array}{l}\text { Use inorganic } \mathrm{P} \\
\text { supplements }\end{array}$} \\
\hline Yes & $114 / 138(83)$ & $26 / 28(93)$ \\
\hline No & $24 / 138(17)$ & $2 / 28(7)$ \\
\hline Blanks & 1 & 3 \\
\hline \multicolumn{3}{|l|}{$\begin{array}{l}\text { Consider P when buying } \\
\text { feed ingredients }\end{array}$} \\
\hline Yes & $49 / 129(38)$ & Not applicable \\
\hline No & $80 / 129(62)$ & Not applicable \\
\hline Blanks & 10 & Not applicable \\
\hline \multicolumn{3}{|l|}{ Analyse manure for $\mathrm{P}$} \\
\hline Yes & $43 / 135(32)$ & $10 / 31(32)$ \\
\hline No & $92 / 135(68)$ & $18 / 31(58)$ \\
\hline Don't know & - & $3 / 31(10)$ \\
\hline Blanks & 4 & - \\
\hline \multicolumn{3}{|l|}{$\begin{array}{l}\text { Aware of P pollution } \\
\text { issues }\end{array}$} \\
\hline Yes & $92 / 134(69)$ & $25 / 26(96)$ \\
\hline No & $42 / 134(31)$ & $1 / 26(4)$ \\
\hline Blanks & 5 & 5 \\
\hline \multicolumn{3}{|l|}{$\begin{array}{l}\text { Satisfied with available P } \\
\text { management training }\end{array}$} \\
\hline Yes & $10 / 132(8)$ & $6 / 31(19)$ \\
\hline No & $97 / 132(73)$ & $21 / 31(68)$ \\
\hline Don't know & $25 / 132(19)$ & $4 / 31(13)$ \\
\hline Blanks & 7 & - \\
\hline
\end{tabular}

${ }^{1}$ Calculated by comparing the dietary $\mathrm{P}$ concentration stated by respondents with the National Research Council (NRC, 2001) recommended concentration that was determined using the DM intake predicted from milk yield stated by respondents.

likelihood that a farm uses inorganic P supplements (Table 3). Farmers operating larger herds were more aware of $\mathrm{P}$ pollution issues and more likely to analyse manure for $\mathrm{P}$, but were more likely to feed P in excess of the NRC (2001) recommendations (Table 4). Pasture-based systems were less likely than housed systems to test their herd's manure for P. Almost all farmers (133/139 [96\%]) were willing to reduce the dietary P concentration of their

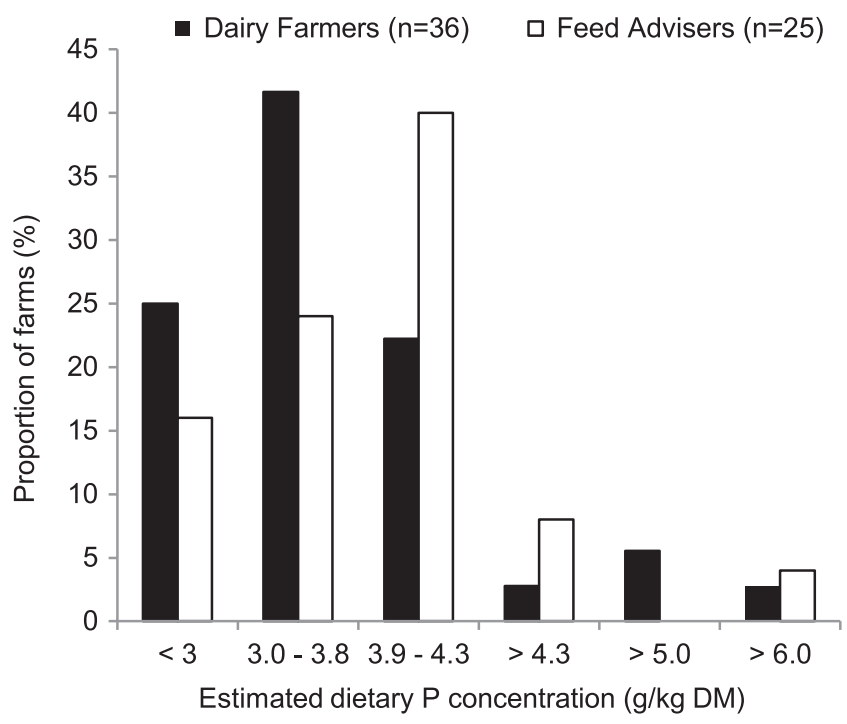

Fig. 1. Dietary phosphorus $(\mathrm{P})$ concentrations $(\mathrm{g} / \mathrm{kg} \mathrm{DM})$ estimated by dairy farmers and feed advisers in Great Britain. Recommended average P concentration in dairy cow diet: $3.5 \mathrm{~g} / \mathrm{kg}$ DM (NRC, 2001) or $4.1 \mathrm{~g} / \mathrm{kg}$ DM (Agricultural and Food Research Council (AFRC), Suttle et al., 1991), based on a cow producing $7956 \mathrm{~kg}$ milk/year (average for participating farmers in this study).

Table 3

Association of phosphorus (P) feeding to dairy cows and management practices that dairy farms adopt with regions, dairy farm classifications and use of a feed professional's advice.

\begin{tabular}{|c|c|c|c|}
\hline $\begin{array}{l}\text { Hypothesis } \\
\mathrm{H}_{\mathrm{o}}\end{array}$ & & Result & $\begin{array}{l}P \text {-value } \\
=\end{array}$ \\
\hline \multicolumn{4}{|c|}{ Associations with regions } \\
\hline & Use inorganic P supplements & $\begin{array}{l}X^{2}(2 \\
n=136)=9.901\end{array}$ & 0.007 \\
\hline \multicolumn{4}{|c|}{ Associations with dairy farm classifications } \\
\hline & Analyse manure for $\mathrm{P}$ & $\begin{array}{l}X^{2}(4 \\
n=136)=11.84\end{array}$ & 0.019 \\
\hline & Feed professional presence & $\begin{array}{l}X^{2}(4 \\
n=138)=15.90\end{array}$ & 0.003 \\
\hline \multicolumn{4}{|c|}{ Associations with feed professional } \\
\hline & $\begin{array}{l}\text { Formulate diets using forage } \mathrm{P} \\
\text { test results }\end{array}$ & $\begin{array}{l}X^{2}(1 \\
n=119)=5.09\end{array}$ & 0.024 \\
\hline & Use inorganic P supplements & $\begin{array}{l}X^{2}(1 \\
n=136)=3.05\end{array}$ & 0.081 \\
\hline
\end{tabular}

Table 4

Association between a dairy farm's herd size and tendency towards adopting certain phosphorus $(\mathrm{P})$ feeding to dairy cows and management practices.

\begin{tabular}{llll}
\hline Characteristic & $P$-value & $\begin{array}{l}\text { Odds } \\
\text { ratio }\end{array}$ & $\begin{array}{l}\text { 95\% Confidence } \\
\text { interval }\end{array}$ \\
\hline $\begin{array}{l}\text { Feed } P \text { in excess of } \\
\text { recommendations }\end{array}$ & $<0.001$ & 1.0072 & $1.0006-1.0138$ \\
$\begin{array}{l}\text { Analyse manure for P } \\
\text { Awareness of P pollution issues }\end{array}$ & $<0.001$ & 1.0049 & $1.0025-1.0074$ \\
\hline
\end{tabular}

${ }^{1}$ Calculated by comparing the dietary $\mathrm{P}$ concentration stated by respondents with the National Research Council (NRC, 2001) recommended concentration that was determined using the DM intake predicted from milk yield stated by respondents.

cows' diet if it was determined that they were feeding $\mathrm{P}$ in excess of $P$ feeding recommendations. This willingness was driven by the prospect of improved environmental and financial sustainability, but the uncertainty of $\mathrm{P}$ availability in different feed ingredients, concerns over reduced cow fertility and lack of information on the $P$ concentration of feed ingredients prevented farmers from reducing $P$ feeding to dairy cows (Table 5). 
Table 5

The barriers to and motivators for reducing dietary phosphorus (P) concentration in lactating cow diets fed on Great Britain dairy farms. ${ }^{1}$

\begin{tabular}{lll}
\hline Barriers and Motivators & $\begin{array}{l}\text { No. of Farmers } \\
(\%)\end{array}$ & $\begin{array}{l}\text { No. of Feed Advisers } \\
(\%)\end{array}$ \\
\hline Barriers & & \\
Uncertainty of P availability & $49 / 166(30)$ & $11 / 42(26)$ \\
$\quad$ Reduced cow fertility & $36 / 166(22)$ & $6 / 42(14)$ \\
Limited feed P concentration & $25 / 166(15)$ & $9 / 42(21)$ \\
data & $23 / 166(14)$ & - \\
Did not know & $15 / 166(9)$ & $9 / 42(21)$ \\
Reduced cow productivity & $11 / 166(7)$ & $1 / 42(2)$ \\
Complicate system & $4 / 166(2)$ & - \\
Nothing & $2 / 166(1)$ & Not applicable \\
Nutritionist advises against & Not applicable & $6 / 42(14)$ \\
Farmers' non-compliance & & \\
Motivators & $76 / 276(28)$ & $14 / 37(38)$ \\
Environmental benefit & $74 / 276(27)$ & $14 / 37(38)$ \\
Reduce feed costs & $70 / 276(25)$ & Not applicable \\
Nutritionist advises it & $37 / 276(13)$ & $7 / 37(19)$ \\
Meeting regulations & $17 / 276(6)$ & $1 / 37(3)$ \\
Incentive programme & $2 / 276(1)$ & $1 / 37(3)$ \\
Animal health &
\end{tabular}

${ }^{1}$ Respondents could select multiple barriers and motivators and so the percentage of responses was calculated using the number of responses to each barrier and motivator not the number of survey respondents.

$2 n=139$.

$3 n=31$.

\section{Survey of feed advisers to dairy farms}

There were 31 responses to the feed adviser questionnaire. The mean herd size of feed advisers' client farms was 357, with a mean annual milk yield of $9560 \mathrm{~kg} / \mathrm{cow}$ and a mean annual amount of concentrate fed at $2529 \mathrm{~kg} / \mathrm{cow}$. More than half of the client farms formulated diets with a P concentration in excess of NRC (2001) recommendations (Fig. 1). Almost half of the feed advisers (10/22 [45\%]) stated that they followed the NRC (2001) recommendations and many feed advisers stated that they used forage $\mathrm{P}$ analysis when formulating diets and used inorganic $P$ supplements (Table 2). Over two-thirds of the feed advisers were not satisfied with the amount of $P$ management training available to them (Table 2). All feed advisers were willing to formulate diets with a lower P concentration, if it was determined that they were feeding $P$ in excess of cows' dietary $P$ requirement. The reasons that will motivate or prevent feed advisers to reduce dietary $\mathrm{P}$ concentrations were same as those reported by dairy farmers (Table 5).

\section{Discussion}

\section{Herd demographics}

The herds of the respondents in the farmer survey had an annual milk yield similar to the UK average of $7889 \mathrm{~kg} / \mathrm{cow}$ (AHDB, 2019a) but were larger than the UK average of 148 cows (AHDB, 2019b). Larger herds were associated with being more aware of $\mathrm{P}$ pollution issues in the US (Dou et al., 2003). Therefore, respondents in the current survey may be representative of farmers more interested in P feeding management. Housed systems operated the largest herds and fed the greatest amount of concentrates per cow to support higher producing cows, which was expected because large herds of high producing cows are easier to manage in housed systems, in regard to controlling the diet (March et al., 2014).

Farmers' knowledge of the phosphorus concentration in lactating cow's diet

It is possible that farmers who reported a dietary P concentration less than $3 \mathrm{~g} \mathrm{P} / \mathrm{kg} \mathrm{DM}$ in the current survey did not consider
P supplied by all dietary sources when reporting dietary P concentration because in England, an average forage mix (forages plus added straight feeds, concentrates and minerals) provides $3.5 \mathrm{~g}$ $\mathrm{P} / \mathrm{kg}$ DM before adding any parlour concentrates (Sinclair and Atkins, 2015). Even though a small proportion of farmers used a $P$ feeding recommendation in the current survey, both NRC and AFRC recommendations for $P$ requirement in dairy cow diets were used, which could make it difficult for farmers to appraise the status of P overfeeding on their farms, because the AFRC (Suttle et al., 1991 ) recommends a higher dietary $P$ requirement in dairy cows than the NRC (2001). Therefore, there is a need to draw farmers' attention towards the most up-to-date $P$ feeding recommendations to minimise the lack of uniformity in following recognised $P$ feeding recommendations and to encourage farmers to accurately work towards feeding $\mathrm{P}$ at the minimum requirement.

Precision phosphorus feeding and management practices used by dairy farmers

A cow's $P$ requirement changes with the stage of lactation and an opportunity exists to lower dietary P concentration by accounting for the resorption of bone in early lactation (Kebreab et al., 2013). Therefore, formulating diets for groups of cows with similar milk yields or in the same lactation stage will allow more precise formulation of diets that will match cows' $\mathrm{P}$ requirement (Kebreab et al., 2013). However, most farmers in the current survey did not implement a group feeding strategy, primarily because it would complicate their feeding system. The ease of a feeding system is important for farmers when choosing management practices and is a primary reason for the increased number of housed systems in GB (March et al., 2014). A group feeding strategy can be simple to adopt in a housed system because diets can be easily controlled but could also be adopted in pasture-based systems by careful grouping of cows e.g. spring block calving. Therefore, promoting group feeding strategies could facilitate the sustainable use of $\mathrm{P}$ in diverse dairy farming systems.

In the current survey, less than half of the farmers that formulated their own diets considered the actual forage P concentration during diet formulation whilst the remaining farmers presumably used book values. However, book values can inaccurately estimate the $P$ concentration of forages, as the concentration varies with forage maturity and soil P levels, leading to imprecise dietary P supply to dairy cows (Cerosaletti et al., 2004). The farms that underestimated forage $\mathrm{P}$ concentrations by using book values could feed excess $\mathrm{P}$ in the form of supplements, and indicate an opportunity to reduce the purchasing of excess inorganic $P$ supplements (Kebreab et al., 2008). Inversely, forage $P$ analysis can reduce the risk of overestimating $\mathrm{P}$ concentrations in forages, minimising the chance of a P-deficient diet being formulated. Promoting regular forage $P$ testing is crucial to optimise $P$ feeding in pasture-based systems, where cows are primarily fed forages, but also in any system when parlour concentrates or inorganic mineral supplements are fed to cows.

Factors influencing farmers' awareness of phosphorus pollution and phosphorus feeding and management practices

In the current study, farms with a feed professional were more likely to regularly analyse their forages for $\mathrm{P}$ than farms without a feed professional. However, the lesser reliance on feed professionals by farmers operating pasture-based systems compared to housed systems highlights that alternative strategies are required to encourage forage $\mathrm{P}$ analysis in pasture-based systems. Such strategies could include subsidisation of sample analyses and provision of $P$ management education through farm advisory services (Knowlton, 2011; Svanback et al., 2019). In future, minimising P 
feeding in pasture-based systems could be more important, because the number of housed systems may not increase or may decline due to consumer's preference for pasture-based systems (March et al., 2014). However, the increasing number of housed systems in GB (March et al., 2014) highlights the importance of the advice of feed professionals in minimising P feeding in modern dairy farming. In the current study, the tendency of farms with a feed professional to use unnecessary inorganic $P$ supplements more than farms without a feed professional suggested that more training on $\mathrm{P}$ management should be offered to feed professionals if the influence that feed professionals could have over $\mathrm{P}$ feeding practice is to be better utilised to minimise P feeding.

Most farmers in the current survey never tested manure $P$ content, suggesting that farmers feeding $P$ in excess of cows' dietary $P$ requirement and adjusting mineral fertiliser $\mathrm{P}$ application rates based on standard values for manure $P$ were not crediting manure $\mathrm{P}$ accurately and therefore, not reducing mineral fertiliser $\mathrm{P}$ application accordingly. Farmers can acquire information on P content of manure before land application by sending representative samples from each batch of manure to a laboratory or by testing such samples with commercially available on-farm colorimetric test kits. However, the cost-effective solution to the challenge of managing $\mathrm{P}$-rich manure remains the minimising of $\mathrm{P}$ feeding because in areas with a high soil $P$ index, farmers may incur additional costs for the transportation of manure to further lands (Knowlton, 2011). However, encouraging manure $\mathrm{P}$ analysis remains important for minimising $\mathrm{P}$ feeding because it provides farmers with an indication of the relative degree of excess $P$ feeding on their farms (Nordqvist et al., 2013). In the current study, farmers of smaller herds were less likely to analyse their manure $P$ than larger herds. It is important to ensure effective manure management in densely stocked herds (Svanback et al., 2019), because of the greater quantities of manure they generate compared to the land available for manure spreading. In the current survey, the higher tendency for manure $\mathrm{P}$ testing in larger herds was also important because larger herds showed a greater tendency to feed P in excess of NRC (2001) recommendations. This was despite farmers of larger herds being more aware of $\mathrm{P}$ pollution issues than smaller herds in the current study and in the US (Dou et al., 2003). Regardless of dairy farming system, the current survey identified that increasing the availability of P management training to dairy farmers is an effective strategy to raise farmers' awareness of $\mathrm{P}$ pollution issues and promote precision $\mathrm{P}$ feeding practices.

Barriers to and motivators for dairy farmers to reduce excess phosphorus feeding

The benefit of reduced feed costs and water pollution associated with minimising P feeding (Kebreab et al., 2008) would motivate farmers to lower dietary P concentrations. However, to minimise $\mathrm{P}$ feeding, the current study indicated that the uncertainty of $\mathrm{P}$ availability in feed ingredients needs to be addressed particularly in pasture-based systems where the P availability of grazed forages varies with soil and fertiliser $P$ concentrations, environmental conditions and management practices (Karn, 2001). The variation in digestibility and absorption of $\mathrm{P}$ by dairy cows influenced by various feed and animal factors (NRC, 2001; Ray et al., 2013) has led farmers and feed advisers in the US to formulate diets following NRC (2001) recommendations but with the addition of a safety margin (Sansinena et al., 1999; Harrison et al., 2012). However, the NRC (2001) recommendations already include a modest safety margin to accommodate the high variability in $\mathrm{P}$ availability between individual feed ingredients within each feed type (forages, concentrations, and inorganic supplements). Therefore, formulating diets following NRC (2001) recommendations could minimise $\mathrm{P}$ feeding, but more precise $\mathrm{P}$ feeding could be achieved by determining $\mathrm{P}$ availability in individual feed ingredients (Feng et al., 2016).

The presence of 'fertility' as a multiple-choice option may have led to overestimation of the relative importance of this barrier. However, fertility concern has caused farmers and feed professionals in the US to resist efforts to minimise P feeding (Dou et al., 2003; Harrison et al., 2012). Concerns over fertility amongst dairy farmers when lowering dietary $\mathrm{P}$ concentrations are possibly related to earlier research that reported the feeding of a dietary $\mathrm{P}$ concentration of $2 \mathrm{~g} / \mathrm{kg}$ DM impaired cow fertility (Knowlton et al., 2004). However, feeding P within the NRC (2001) recommended range has no adverse effect on fertility or productivity (Ferris et al., 2009). Therefore, farmers should be educated on the most recent findings on the effects of dietary $\mathrm{P}$ concentration on cow fertility.

\section{Survey of feed advisers to dairy farms}

The feed advisers generally demonstrated a greater knowledge of $P$ feeding than the average farmer survey respondent. However, over half of the feed advisers' client farms formulated lactating cow diets with a P concentration in excess of NRC (2001) recommended dietary $P$ requirement. Increased knowledge transfer could encourage feed advisers to minimise $P$ feeding because feed advisers were similarly unsatisfied with the amount of $\mathrm{P}$ management training available to them as dairy farmers. This knowledge transfer should utilise the feed advisers' motivators for minimising P feeding and address their barriers to minimising P feeding, which were similar to those reported by the dairy farmers in the current study.

\section{Conclusions}

Most dairy farmers were not aware of how much P they are feeding or how much they should be feeding to their cows and instead relied on feed professionals. Feed professionals have an important influence over P feeding practice, particularly in housed systems. Therefore, the better utilisation of feed professionals' influence over $P$ feeding to minimise $P$ feeding is increasingly important as the number of housed dairy farming systems in GB has increased. Furthermore, it is important to consider the type of dairy farming systems when developing precision $\mathrm{P}$ feeding strategies. Farmers were willing to reduce dietary $\mathrm{P}$ concentrations but to facilitate judicious use of $P$, policymakers and research agencies should consider the following strategies: (1) increase the availability of $P$ management education to emphasise the benefits of precision $\mathrm{P}$ feeding and (2) more effectively utilise feed professionals' influence over $\mathrm{P}$ feeding practices on dairy farms to promote precision $\mathrm{P}$ feeding practices and lower dietary $\mathrm{P}$ concentrations in formulated diets.

\section{Supplementary material}

Supplementary data to this article can be found online at https://doi.org/10.1016/j.animal.2021.100248.

\section{Ethics approval}

The questionnaire was approved by the University of Reading's Ethics Committee.

\section{Data and model availability statement}

None of the data were deposited in an official repository. The data that support the study findings are confidential. 


\section{Author ORCIDs}

Brad Harrison: https://orcid.org/0000-0003-3791-049X.

Martina Dorigo: https://orcid.org/0000-0002-9645-911X.

Christopher Reynolds: https://orcid.org/0000-0002-41521190.

Liam Sinclair: https://orcid.org/0000-0002-8543-0063.

Partha Ray: https://orcid.org/0000-0001-8375-8279.

\section{Author contributions}

Brad Harrison: Conceptualization, Methodology, Formal analysis, Investigation, Writing - original draft. Martina Dorigo: Methodology, Writing - review \& editing. Christopher Rynolds: Methodology, Writing - review \& editing. Liam Sinclair: Methodology, Writing - review \& editing. Partha Ray: Conceptualization, Methodology, Writing - review \& editing, Supervision, Funding acquisition.

\section{Declaration of interest}

None.

\section{Acknowledgements}

We are thankful to all those who helped shape the questionnaire, to those who played a role in recruitment and to the participating farmers and advisers.

\section{Financial support statement}

This research was funded by AHDB Dairy (41110062).

\section{References}

AHDB, 2019a. UK Producer Numbers. Retrieved on 18 June 2020 from https://ahdb. org.uk/dairy/uk-producer-numbers.

AHDB, 2019b. UK Cow Numbers. Retrieved on 18 June 2020 from https://ahdb.org. uk/dairy/uk-and-eu-cow-numbers.

Augère-Granier, M., 2018. The EU dairy sector: Main features, challenges and prospects. European Parliamentary Research Service. European Union, Brussels, Belgium.

Cerosaletti, P.E., Fox, D.G., Chase, L.E., 2004. Phosphorus reduction through precision feeding of dairy cattle. Journal of Dairy Science 87, 2314-2323.

Dou, Z., Knowlton, K.F., Kohn, R.A., Wu, Z., Satter, L.D., Zhang, G., Toth, J.D., Ferguson, J.D., 2002. Phosphorus characteristics of dairy feces affected by diets. Journal of Environmental Quality 31, 2058-2065.

Dou, Z., Ferguson, J.D., Fiorini, J., Toth, J.D., Alexander, S.M., Chase, L.E, Ryan, C.M. Knowlton, K.F., Kohn, R.A., Peterson, A.B., Sims, J.T., Wu, Z., 2003. Phosphorus feeding levels and critical control points on dairy farms. Journal of Dairy Science 86, 3787-3795.

European Commission 1991,Council Directive 91/676/EEC of 12 December 1991 concerning the protection of waters against pollution caused by nitrates from agricultural sources. Retrieved on 18 June 2020 from https://eur-lex.europa.eu/ legal-content/EN/TXT/?uri=CELEX:31991L0676.

Feng, X., Jarrett, J.P., Knowlton, K.F., James, R.E., Hanigan, M.D., 2016. Short communication: Comparison of predicted dietary phosphorus balance using bioavailabilities from the NRC (2001) and Virginia Tech model. Journal of Dairy Science 99, 1237-1241.

Ferris, C.P., McCoy, M.A., Patterson, D.C., Kilpatrick, D.J., 2009. Effect of offering dairy cows diets differing in phosphorus concentration over four successive lactations: 2. Health, fertility, bone phosphorus reserves and nutrient utilisation. Animal 4, 560-571.

Garnsworthy, P.C., Gregson, E., Margerison, J.K., Wilson, P., Goodman, J.R., Gibbons, J., Dorigo, M., Topliff, M., 2019. Whole farm feed efficiency on British dairy farms. Proceedings of the British Society of Animal Science, 9-11 April 2019, Edinburgh, UK, p. 193.

Harrison, J., Knowlton, K., James, B., Hanigan, M.D., Stallings, C., Whitefield, E., 2012. Case Study: National survey of barriers related to precision phosphorus feeding. The Professional Animal Scientist 28, 564-568.

Karn, J.F., 2001. Phosphorus nutrition of grazing cattle: a review. Animal Feed Science and Technology 89, 133-153.

Kebreab, E., Hansen, A.V., Leytem, B., 2013. Feed management practices to reduce manure phosphorus excretion in dairy cattle. Advances in Biosciences 4, 37-41.

Kebreab, E., Odongo, N.E., McBride, B.W., Hanigan, M.D., France, J., 2008. Phosphorus utilization and environmental and economic implications of reducing phosphorus pollution from Ontario dairy cows. Journal of Dairy Science 91, 241-246.

Knowlton, K., Ray, P., 2013. Water related issues in sustainability: Nitrogen and Phosphorous management. In: Kebreab, E. (Ed.), Sustainable Animal Agriculture. CAB International, Blacksburg, VA, USA, pp. 113-123.

Knowlton, K.F., 2011. Strategies to reduce phosphorus losses from dairy farm. Advances in Dairy Technology 23, 299-309.

Knowlton, K.F., Radcliffe, J.S., Novak, C.L., Emmerson, D.A., 2004. Animal management to reduce phosphorus losses to the environment. Journal of Animal Science 82, 173-195.

March, M.D., Haskell, M.J., Chagunda, M.G.G., Langford, F.M., Roberts, D.J., 2014. Current trends in British dairy management regimens. Journal of Dairy Science 97, 7985-7994.

Moxey, A., 2012. Agriculture and Water Quality: Monetary Costs and Benefits across OECD Countries. OECD Publishing, Edinburgh, UK.

Nordqvist, M., Holtenius, K., Sporndly, R., 2013. Methods for assessing phosphorus overfeeding on organic and conventional dairy farms. Animal 8, 286-292.

National Research Council (NRC), 2001. Nutrient Requirements of Dairy Cattle. National Academy Press, Washington, DC, USA.

O'Brien, D., Shalloo, L., Patton, J., Buckley, F., Grainger, C., Wallace, M., 2012. A life cycle assessment of seasonal grass-based and confinement dairy farms. Agricultural Systems 107, 33-46.

Ray, P.P., Jarrett, J., Knowlton, K.F., 2013. Effect of dietary phytate on phosphorus digestibility in dairy cows. Journal of Dairy Science 96, 1156-1163.

Sansinena, M., Bunting, L.D., Stokes, S.R., Jordan, E.R., 1999. A survey of trends and rationales for dietary phosphorus recommendations among mid-south dairy nutritionists. In Proceedings of The Mid-South Ruminant Nutrition Conference, January 1999, Dallas, TX, USA, pp. 51-54.

Sinclair, L.A., Atkins, N.E., 2015. Intake of selected minerals on commercial dairy herds in central and northern England in comparison with requirements. Journal of Agricultural Science 153, 743-752.

Suttle, N.F., Armstrong, D.G., Braithwaite, G.D., Field, A.C., Scott, D., Thompson, J.K. Woolliams, J., 1991. A reappraisal of the calcium and phosphorus requirements of sheep and cattle. Nutrition Abstracts and Reviews B: Feeds and Feedstuffs 61 , $573-612$.

Svanback, A., McCrackin, M.L., Swaney, D.P., Linefur, H., Gustafsson, B.G., Howarth, R.W., Humborg, C., 2019. Reducing agricultural nutrient surpluses in a large catchment - Links to livestock density. Science of The Total Environment 648, 1549-1559.

Wang, C., Liu, Z., Wang, D., Liu, J., Liu, H., Wu, Z., 2014. Effect of dietary P content on milk production and phosphorus excretion in dairy cows. Journal of Animal Science and Biotechnology 5, 23. 